\title{
Mitral Valve Fenestration as a Rare Cause of Congenital Mitral Insufficiency Successfully Repaired
}

Francisco Fernandes Moreira Neto ${ }^{1,2,3}$, MD, MSc; Thiago S. Arantes ${ }^{1,3}$, MD; Mauro Cruz Jurca ${ }^{2,4}$, MD; Maria Rita F. S. Moreira $^{1,2,3}$, DDS, MS; Cecilio A. Barbosa Jacob ${ }^{1,2,3}$, Ccp

象

DOI: $10.21470 / 1678-9741-2020-0262$

\begin{abstract}
A rare case of congenital mitral insufficiency characterized by a fenestration in the anterior leaflet of mitral valve is reported. At operation, the mitral valve was successfully repaired by closure of
\end{abstract}

unusual valvular tissue orifice with bovine pericardium and suture of the free edge between $A 1$ and $A 2$ without a ring annuloplasty.

Keywords: Mitral Valve Insufficiency. Tricuspid Valve. Heart Valve Diseases. Sutures. Pericardium.

\section{Abbreviations, acronyms \& symbols}

MR = Mitral regurgitation

MV = Mitral valve

PDA = Patent ductus arteriosus

\section{CASE PRESENTATION}

The patient was born and then sent home the day after a standard cesarean delivery. He had his first regular pediatrician visit at 30 days of age and presented symptoms of shortness of breath. Due to quickly worsening symptoms, he returned to the emergency room when he was 2 months old, with severe dyspnea, hypotension, and had a cardiac arrest. After resuscitation maneuvers were successful, an emergency echocardiographic study revealed severe coarctation of the aorta, small patent ductus arteriosus (PDA), enlarged left atrium and ventricle, bicuspid aortic valve, and moderate mitral regurgitation (MR) (prolapsed anterior leaflet).

The prostaglandin was initiated, and the patient was brought to the operating room. The repair was done via left thoracotomy and, in addition to the coarctation and PDA, we also found an undiagnosed aberrant right subclavian artery originating in the descending aorta. Both were repaired. Against the odds, the MR persisted, even with almost absent aortic gradient and normal left ventricular function. Since the postoperative echocardiography failed to show an easily repairable lesion (now described as parachute valve), he was sent home with full treatment of diuretics, vasodilators, and digoxin.

In the follow-up, when he was 5 months old, he had persistent cardiac failure symptoms and was readmitted with New York Heart Association class IV. Marked cardiomegaly with the left atrium as the predominant chamber was seen on the chest radiograph associated with signs of pulmonary congestion. Electrocardiography showed sinus rhythm, right-axis deviation, and left atrium hypertrophy. The new cross-sectional echocardiography revealed a perforation in the anterior leaflet of the mitral valve (MV) (Figure 1 and Video 1) and the surgery was immediately recommended.

\section{TECHNICAL DESCRIPTION}

Surgery was performed via a median sternotomy, using cardiopulmonary bypass, with moderate hypothermia $\left(28^{\circ} \mathrm{C}\right)$ and cold potassium cardioplegia, and we could see a very
'Clínica de Cirurgia Cardiovascular, Ribeirão Preto, São Paulo, Brazil.

${ }^{2}$ Department of Surgery, Faculdade de Medicina, Universidade de São Paulo, Ribeirão Preto, São Paulo, Brazil.

${ }^{3}$ Hospital São Lucas, Ribeirão Preto, São Paulo, Brazil.

4Prolmagem Medicina Diagnóstica de Ribeirão Preto, São Paulo, Brazil.

This study was carried out at the Clínica Cirúrgica do Tórax, Ribeirão Preto, São Paulo, Brazil.
Correspondence Address:

Francisco F. Moreira Neto

(iD) https://orcid.org/0000-0001-9818-9224

Clínica Cirúrgica do Tórax

Rua Quintino Bocaiúva, 258, Ribeirão Preto, São Paulo, Brazil - Zip Code: 14015-13 E-mail:franmoreira@conjunturabrasil.com.br Article accepted on July $4^{\text {th }}, 2020$. 
more difficult to find an MR caused by a deficient tissue growth like a fenestration in the anterior leaflet, like this case ${ }^{[3]}$. An understanding of the pathologic anatomy of congenital MR is absolutely relevant to its optimal surgical management. If one recognizes that regurgitation is due to a leaflet perforation, it may well be possible to patch the perforation, thereby avoiding MV replacement.

\section{ACKNOWLEDGEMENTS}

Dr. Paulo Roberto B. Évora for the encouragement and his academic thoughts.

\section{REFERENCES}

1. Kalangos A, Oberhansli I, Khatchatourian G, Friedli B, Faidutti B. Multipleleaflet mitral valve as a rare cause of congenital mitral insufficiency. Ann Thorac Surg. 1997;63(5):1452-5. doi:10.1016/s0003-4975(97)00108-2.

2. Freed MD, Keane JF, Van Praagh R, Castañeda AR, Bernhard WF, Nadas AS. Coarctation of the aorta with congenital mitral regurgitation. Circulation. 1974;49(6):1175-84. doi:10.1161/01.cir.49.6.1175.

3. Oztunç F, Saltik IL, Türkoğlu H. Mitral perforation: a rare cause of congenital mitral regurgitation. Cardiol Young. 2003;13(5):472-4.

\section{No financial support.}

No conflicts of interest.

\section{Authors' roles \& responsibilities}

FFMN Substantial contributions to the conception or design of the work; or the acquisition, analysis or interpretation of data for the work; drafting the work or revising it critically for important intellectual content; final approval of the version to be published

TSA Substantial contributions to the conception or design of the work; final approval of the version to be published

MCJ Substantial contributions to the conception or design of the work; and acquisition of data for the work

MRFSM Agreement to be accountable for all aspects of the work in ensuring that questions related to the accuracy of integrity of any part of the work are appropriately investigated and resolved; final approval of the version to be published

CABJ Substantial contributions to the conception or design of the work; final approval of the version to be published 